\title{
THE EFFECT OF TRANSPORT AND LOGISTICS ON TRADE FACILITATION AND TRADE: A PLS-SEM APPROACH
}

\author{
Cynthia Sénquiz-Díaz ${ }^{1}$
}

Received 19. 06. 2021.

Sent to review 22. 06. 2021.

Accepted 02. 09. 2021.

\section{Original Article}

${ }^{1}$ Universidad Ana G. Méndez, Division of Business, Tourism \& Entrepreneurship, Gurabo, Puerto Rico

\section{Corresponding Author:}

Cynthia Sénquiz-Díaz

Email: cynthia.senquiz@gmail.com

\section{JEL Classification:}

C30, O19, P33, L91, M16

Doi: 10.2478/eoik-2021-0021

UDK: 005.336.4:005.336.1

\begin{abstract}
Trade facilitation promotes increased opportunities to participate in international trade. Current research has mainly analyzed the impacts of tariff-related and trade barriers. Nevertheless, as trade policies shift toward removing non-tariff barriers, studies addressing core elements become relevant, requiring a more systemic view at a simultaneous level. The study proposes that transportation infrastructure (i.e., roads, seaports, railroads, and airports) and logistics are core elements supporting trade facilitation efforts at the local level. The study provides empirical evidence on the direct and indirect effects among transportation infrastructure, logistics, trade facilitation, and trade. Partial least squares-structural equation modeling is the main empirical method employed to examine the interrelationship of the quality of transportation infrastructure, logistics, trade facilitation, and trade using a sample of 80 countries for the years 2012, 2014, and 2016. There is a large direct effect of transportation infrastructure on trade facilitation and a vast direct effect on logistics. Logistics has a small direct effect on trade facilitation. I also conduct mediation analyses, which show that logistics has a larger effect on trade via trade facilitation than transportation infrastructure quality has. These findings suggest that trade facilitation implementation might not be enough to tackle current challenges and ongoing economic development. Governments should prioritize the integration of logistics stakeholders in the public sector to optimize the benefits of global networks. Thus, the significance of transportation infrastructure and logistics in trade should not be neglected, as the private sector (i.e., logistics providers) play a large and relevant role in practice.
\end{abstract}

Keywords: trade facilitation, infrastructure of services, stakeholders, logistics, transportation infrastructure, PLS-SEM, effect sizes, formative model

\section{INTRODUCTION}

Economic theory suggests a relatively direct and simple chain of causality: human development is enhanced through income growth, income growth is greater with more cross-border trade; trade is increased through trade facilitation efforts (Wilson, Mann, \& Otsuki, 2003, p. 367).

There are undeniable gains to embracing trade facilitation efforts, which are designed to streamline and simplify trade measures. Trade facilitation promotes increased opportunities to participate in international trade, driving countries to improve their competitiveness in the world economy and citizens' lives. Moreover, trade facilitation is beneficial and relevant to governments, society, 
and related stakeholders (Grainger, 2011). The implementation and further development of trade facilitation will depend on coordinated efforts to provide a better trade-related environment based on services and strategies.

Research on trade facilitation has been devoted to analyzing the impacts of tariff-related and trade barriers, mostly employing the gravity model (Marquez-Ramos, Martínez-Zarzoso, \& Suárez-Burget, 2012; Wilson, Mann, \& Otsuki, 2005; Yadav, 2014). Nevertheless, as trade policies shift toward removing non-tariff barriers, studies addressing core elements become relevant, demanding a more comprehensive and systemic view. In this sense, many trade obstacles, such as customs clearance delays and inefficiency of infrastructure services, can negatively impact market access, making policies essential for trade advancement facilitation (Hoekman \& Nicita, 2010) in an integrated framework. This fact has underpinned many of the attempts to forge global trade agreements, from the Doha Round of the World Trade Organization (WTO) launched in 2001, to the Trade Facilitation Agreement reached by WTO members in 2017. As a result, government reforms and trade agreements have reduced barriers to cross-border goods flows, leading to greater global integration (Hoekman \& Nicita, 2010) but adding immediate challenges that have not yet been sufficiently discussed even in the Trade Facilitation Agreement of 2017. This study assumes that transportation infrastructure (i.e., roads, seaports, railroads, and airports) and logistics are core elements supporting trade facilitation for successful trade at the local level. The quality of transportation infrastructure aids the arrangement of global production networks in dealing with worldwide markets (Hummels, 2007). Transportation infrastructure supports economic growth and development by increasing trade and promoting electronic governance, connectivity, and simplification (UNCTAD, 2016). On the one hand, transportation infrastructure has been widely analyzed from a cost and distance perspective. Moreover, the urge to reduce distances through infrastructure development has encouraged public spending on transportation projects. On the other hand, logistics has been largely explored from a microeconomic perspective, focusing on businesses' cost control and customer service, and has seldom been examined at the country level in trade facilitation research. The present study aims to fill this research gap. Furthermore, there is a lack of studies examining the impacts of transportation infrastructure, logistics, and trade facilitation in trade using complex relationships simultaneously. The purpose of this study is to measure the direct and indirect effects among transportation infrastructure, logistics, trade facilitation, and trade based on a sample of 80 countries for the years 2012, 2014, and 2016. The research employs partial least squares (PLS) with structural equation modeling (SEM), allowing simultaneous and complex analyses. Hence, integrating separate components (i.e., transportation infrastructure and logistics) is expected to provide a better means of assessing firms' performance in global markets with government assistance.

\section{THEORETICAL FRAMEWORK}

This research is based on the social capital literature and is informed by the resourcebased view (RBV), stakeholder theory, and resource dependence (RD) theory. The RBV describes the proper allocation and use of resources within a network. In this context, the assets from the transportation industry and soft resources from the logistics sector should be combined to expand possibilities for economies to trade in global markets (Sénquiz-Díaz, 2021a; Yang \& Lirn, 2017) once identified and properly allocated. Stakeholder theory supports the interdependency of different actors and sectors taking part in trade exchanges, in which local coordination affects countries' integration in the global economy. Lastly, the RD theory adds to the strategic thinking associated with forming network ties to increase the significance and optimal use of different resources. 


\section{LITERATURE VIEW}

\subsection{TRADE}

Trade is essential for supporting economic development and setting harmonious relations between nations (WTO, n.d.). As such, it involves transactions for flows between markets (Rodrigue \& Comtois, 2017). These activities depend on a country's openness and size, typically measured as the total value of exports and imports (goods and services) to gross domestic product (GDP) (Kuznets, 1959). Previous research has revealed several perspectives on how trade activities, particularly imports of certain commodities, affect the economy's productivity. For example, Lee (1995) verified the importance of less developed nations having less costly capital goods, as it increases productivity based on national price disparities. Herzer (2007) showed that in Chile, a 1\% increase in capital goods led to a $0.16 \%$ gain in productivity, whereas a $1 \%$ increase in intermediate imports boosted productivity by $0.047 \%$. Veeramani (2008) concluded that the source of capital and intermediate goods imports matters for productivity. The findings underline the significance of imports from wealthier countries and their impact on long-run growth because of knowledge diffusion. Enterprise leaders decide what to produce and which goods to trade across borders. The government motivates these decisions when embracing different means of trade facilitation. In every business decision, a network in a country is impacted, including the final customers and citizens of local countries. These trade-related activities impact the competitiveness levels of countries (Mann, 2012). In this sense, firms are prompted to import capital and intermediate goods (International Trade Forum, 2013). However, trade barriers in economies and slowing global trade may discourage goods investment, such as in low-income nations, when integration is critical for decreasing the relative price of such investments (Lian, Novta, Pugacheva, Timmer, \& Topalova, 2019). This scenario could be problematic, as economies may rely on goods exchanges for (1) development and living enhancement and (2) domestic revenue generation (Hausman, Lee, \& Subramanian, 2013).

\subsection{TRADE FACILITATION}

Economic and trade perspectives provide a framework for understanding why countries should trade even for the goods they can create. Comparative and absolute advantage theories provide the foundations to sustain a country's opening to foreign markets, stimulating domestic firms to increase productivity (Hill, 2011), which may benefit regions (Helpman \& Krugman, 1989). A current challenge in countries is managing exogenous and endogenous factors that impact trade-related costs (UNCTAD, 2016). While the former is beyond a country's control, the latter is inextricably linked to the country's domestic policies (UNCTAD, 2016). Previous research shows that reducing trade barriers positively impacts countries. Zhang, Li, Yu, and Cheng (2019) indicated that the simplicity of customs processes favors a country's efficiency. Tariffs and the burden of customs procedures have proven to have a detrimental influence on commerce. Inefficient export and import procedures, for example, and excessive red tape raise the cost of doing business in countries (International Trade Forum, 2013). Furthermore, a country's lack of transparency on document compliance lengthens the projected delivery time. Errors in shipping document declarations contribute to the time required for customs clearance, motivating traderelated corruption to minimize these delays (UNCTAD, 2016). Moreover, the availability and adoption of technology opens new avenues for increasing the number of export items. For example, Freund and Weinhold (2004) showed that a $10 \%$ increase in a country's web hosts is correlated with a $10 \%$ increase in exports. The prevalence of non-tariff barriers has been shown to have a positive and significant effect on facilitating trade. However, current research produces mixed findings. For example, Hoekman and Nicita (2008) showed that non-tariff barriers restrict trade, particularly 
for lower-income economies. By contrast, Cipollina and Demaria (2020) suggested that nontariff barriers could enhance trade in some countries but may incur additional costs, detracting from such opportunities. Trade facilitation execution has proved its purpose in other sectors. For example, the OECD (2020) indicated that global health events, such as the COVID-19 pandemic, stress the significance of trade facilitation measures to ensure smooth movements of products. However, current constraints regarding cargo shipping, social interaction, limited personnel, and access to possible contaminated areas have raised freight costs and negatively impacted timely deliveries. This situation may jeopardize businesses worldwide, particularly small and mediumsized enterprises, which may be more dependent on trading exchanges, especially imports.

Based on the discussion, the following hypothesis is proposed.

H1: Trade facilitation implementation have a positive effect on trade.

\subsection{QUALITY OF TRANSPORTATION INFRASTRUCTURE}

Transportation infrastructure is an essential component of an economy regarding opportunities for trading goods. It describes common physical assets, such as roads, ports, airports, and railroads (Skorobogatova \& Kuzmina-Merlino, 2017). Their quality lays the basis for a country's international competitiveness (Lakshmanan, 2008; OECD, 2013) and better integration into the global economy and development (Portugal-Pérez \& Wilson, 2010). For the purpose of the study, quality of transportation infrastructure, transport and transportation are interchangeable concepts. Previous research has emphasized the significance of transportation infrastructure quality in logistics. Korinek and Sourdin (2011) indicated that high-quality infrastructure influences logistics performance, whereby economies with lower quality infrastructure may benefit from incremental development. Developing economies seem to be a good example of how much governments rely on these infrastructure qualities. For example, according to Lean, Huang, and Hong (2014), China constantly invests in physical infrastructure with the aim of boosting exports and imports. The authors showed the urgent need to develop the logistics sector, including by improving regulations, considering relevant logistics factors, and developing logistics professionals' capabilities. A network of services, in high demand for many cross-border transactions, is necessary mainly to complete production and in recent years has been a critical feature of the international economy (Saslavsky \& Shepherd, 2014). Therefore, trade facilitation efforts might not be sufficient to increase trade opportunities. The quality of transportation infrastructure is essential for trade facilitation and trade, as shown by Portugal-Pérez and Wilson (2010); the research focus is on the quantification of effects due to the integrated infrastructure of services and not on causation between increases in trade and transportation. Moreover, the interdependence of these assets within infrastructure provision is irrelevant if operators do not support the gains of trade facilitation and exchanges (Kodongo \& Ojah, 2016).

Based on the literature, the following hypotheses are proposed.

$\mathrm{H} 2$ : The quality of transportation infrastructure has a positive effect on logistics.

H3: The quality of transportation infrastructure has a positive effect on trade facilitation.

H4: The quality of transportation infrastructure has a positive effect on trade.

H5: The quality of transportation infrastructure positively influences the relationship between trade facilitation and trade.

\subsection{LOGISTICS}

"Better logistics performance is associated with trade expansion, export diversification, ability to attract foreign direct investment, and economic growth" (Kunaka, Mustra, \& Saez, 2013, 
p. 5). Meanwhile, inefficient logistics services interfere with the facilitation of trading by incurring additional time and costs (Korinek \& Sourdin, 2011), and thereby adversely influencing the business use of transportation assets for a country's development and growth (Limão \& Venables, 2001). For this study, logistics and logistics performance are interchangeable concepts. Previous studies have concluded that logistics performance is critical for increasing competitiveness. Gani (2017), for example, demonstrated a considerable impact of logistics performance, primarily on exports and partially on imports of products and services. His findings highlight speed and quality of service as facilitators of higher imports and a strong linkage between logistics performance and exports, implying that enhanced logistics performance increases global trade. D'Aleo and Sergi (2017) provided evidence that logistics performance has a favorable and direct impact on expansion of exports in Europe. Munim and Schramm (2018) explored the role of logistics in seaborne trade and concluded that greater levels of logistics performance would increase trade. Behar, Manners, and Nelson (2013) provided evidence that export logistics enhanced exports of developing countries while Sénquiz-Díaz (2021b) showed that logistics is a significant component of exports from developing countries. Logistics has a considerable impact on the facilitation of international commerce. It improves the country-to-country connections between foreign and domestic markets (Arvis et al., 2018). In addition, Martí, Puertas, and García (2014) found that nations that improve their logistics efficiency and performance also increase their trade, based on data from economies with a maritime border between 2005 and 2010. Hoekman (2012, par. 1) stated that "even if tariffs on export markets are zero if firms in a country confront high cost and inefficient logistics, they will not be able to compete with firms that benefit from an efficient logistics environment."

The following hypotheses are proposed.

H6: Logistics has a positive effect on trade facilitation.

H7: Logistics has a positive effect on trade.

H8: Logistics positively reinforces the relationship between trade facilitation and trade.

Figure 1 presents the conceptual model developed based on the direct hypotheses. Figures 2 and 3 present the research models for the proposed indirect hypotheses (H5 and H8).

Figure 1. Conceptual model-Direct hypotheses.

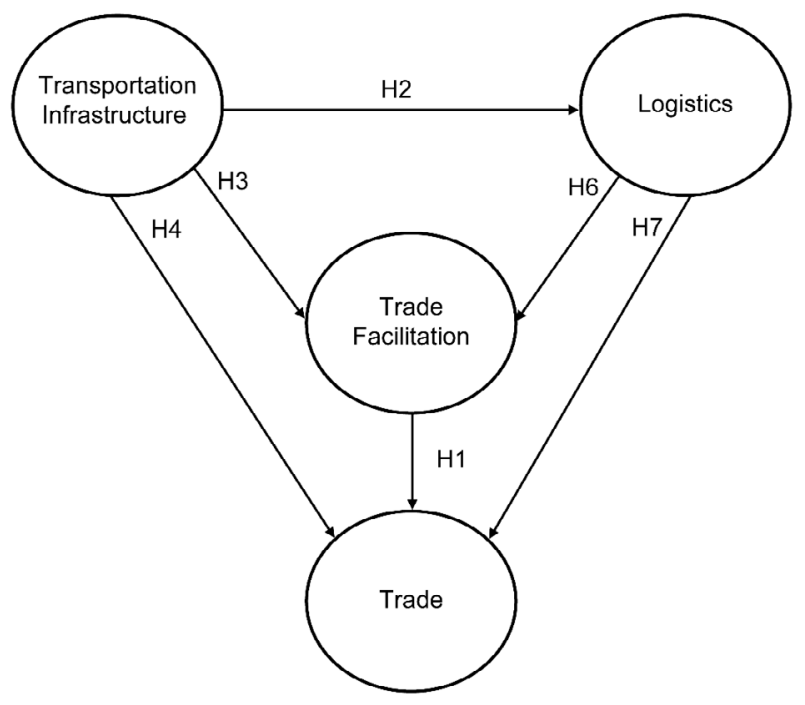

Source: Author's elaboration. 
Figure 2. Conceptual model-Indirect hypothesis (H5).

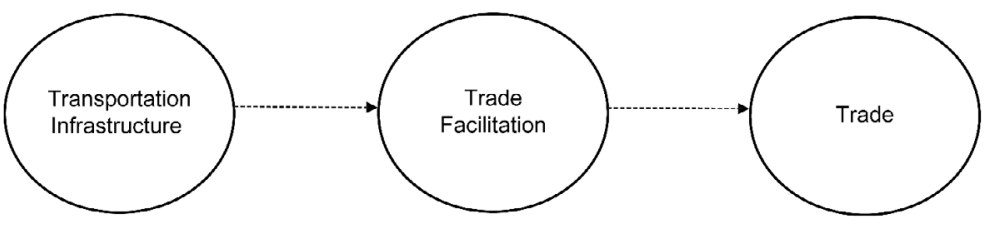

Source: Author's elaboration.

Figure 3. Conceptual model-Indirect hypothesis (H8)

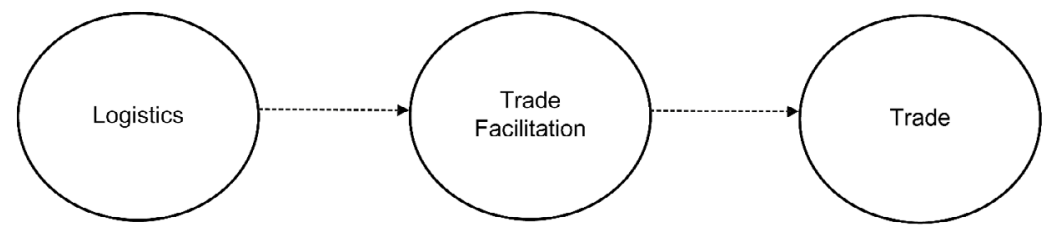

Source: Author's elaboration.

\section{DATA AND METHODS}

The study has an experimental design based on secondary data from 80 countries for 2012, 2014, and 2016. The multiple indicators were used to form the latent constructs. The main criteria for selecting the countries were data availability. Appendix 1 shows a list of the countries. Transportation infrastructure quality is the only exogenous construct in the model formed by the quality of the most common freight modes (i.e., roads, ports, airports, and railroads). The data are derived from the Global Competitiveness Report (GCR) issued by the World Economic Forum (WEF) following the work of Portugal-Pérez and Wilson (2010) and Sénquiz-Díaz (2021a). The global indicators employed for the redundancy analysis were obtained from the GCR. Trade facilitation data were also derived from the GCR as well as the Global Enabling Trade Report (GETR), which is also issued by the WEF. The GETR provides information on openness to foreign markets. Its utilization in this research is partially based on Portugal-Pérez and Wilson (2010), with extended indicators (Sénquiz-Díaz, 2021c). Logistics data were obtained from the biennial World Bank (WB) Logistics Performance Index (LPI), which comprises the average of six dimensions: (1) customs efficiency, (2) infrastructure, (3) international shipments, (4) logistics competencies, (5) tracking and tracing, and (6) timeliness. The LPI is based on a Likert questionnaire of private freight forwarders and shippers in nations that currently use shared transportation assets. The endogenous variable, trade, was proxied by exports of goods to GDP (ExGDP) following Munemo, Bandyopadhyay, and Basistha (2006) and imports of intermediate and capital goods-to-GDP (MincGDP) following Fernández-Núñez, Maesso, and Márquez (2017) and Herzer (2007). Trade figures were drawn from the World Integrated Trade Solution, while GDP figures were obtained from the WB. Trade in services was excluded, as the study focuses on the cross-border movements of physical goods, aligning with the United Nations (2013). These figures were transformed into natural logarithms $(\mathrm{ln})$. Trade facilitation research advocates the use of latent constructs and a variety of indicators. Hence, this study employed PLS-SEM (Ringle, Wende, and Becker, 2015), which is a novel method in trade facilitation research. PLS-SEM is useful because it (1) permits multivariate analysis to identify effects concurrently and (2) handles non-normal data effectively (Hair, Hult, Ringle, \& Sarstedt, 2017). Its selection was motivated by the opportunity to observe the interaction of several components at a more complex level. The structural model assumes a formative measurement following the theoretical and empirical guidelines suggested by Coltman, 
Devinney, Midgley, and Venaik (2008), subjected to validity confirmation (Hair et al., 2017). In addition, the mediation analysis suggested by Zhao, Lynch, and Chen (2010) and Hair et al. (2017) was used to examine the indirect effects of transport and logistics, as suggested by H5 and H8. Appendix 2 summarizes the latent constructs with formative indicators, abbreviations, and data sources.

\section{RESULTS}

Table 1 displays the summary statistics for the research variables for the 80 sample countries. Overall, countries seem to make similar trade facilitation efforts. The findings suggest there are economies with a more complex tariff structure that show interest in participating in foreign markets. In addition, export-led orientation is a strategy for some countries, while it is common for countries to import capital and intermediate goods.

Table 1. Summary statistics of variables.

\begin{tabular}{lllllllll}
\hline & Indicators & Mean & Median & SD & Min & Max & Skewness & $\begin{array}{l}\text { Excess } \\
\text { Kurtosis }\end{array}$ \\
\hline Qtransp & qrds & 4.19 & 4.10 & 1.17 & 2.00 & 6.30 & 0.10 & -1.19 \\
& qprts & 4.32 & 4.40 & 1.11 & 1.30 & 6.80 & -0.05 & -0.45 \\
& qarps & 4.67 & 4.60 & 1.00 & 2.20 & 6.65 & -0.05 & -0.91 \\
& qrrs & 3.54 & 3.35 & 1.32 & 1.20 & 6.70 & 0.43 & -0.62 \\
Logp & log & 3.18 & 3.16 & 0.56 & 1.85 & 4.23 & -0.01 & -0.98 \\
Trafa & tarcom & 4.72 & 4.90 & 1.51 & 1.70 & 7.00 & 0.01 & -1.56 \\
& govpol & 4.29 & 4.20 & 0.80 & 2.50 & 6.20 & 0.34 & -0.40 \\
& opfor & 4.51 & 4.50 & 0.56 & 2.70 & 5.75 & -0.59 & 0.34 \\
& nontar & 4.43 & 4.45 & 0.52 & 2.60 & 5.80 & -0.27 & 0.71 \\
& custpr & 4.31 & 4.30 & 0.82 & 2.00 & 6.20 & 0.01 & -0.49 \\
& techab & 4.81 & 4.80 & 0.70 & 3.40 & 6.15 & 0.05 & -0.98 \\
& LnXGDP & -1.73 & -1.67 & 0.85 & -3.76 & 0.55 & 0.04 & -0.48 \\
& LnMincGDP & -2.03 & -2.10 & 0.70 & -3.72 & 0.55 & 0.55 & 0.66 \\
\hline
\end{tabular}

Table 1. qtransp (quality of transportation infrastructure), qrds (quality of roads), qprts (quality of ports), qarps (quality of airports), qrrs (quality of railroads), logp (logistics performance), log (logistics), trafa (trade facilitation), tarcom (tariff complexity), govpol (government policymaking), opfor (openness to foreign markets), nontar (prevalence of trade barriers), custpr (customs procedures), techab (technology absorption), trd (trade), LnXGDP (exports of goods to GDP), LnMincGDP (imports of intermediate and capital goods to GDP)

Source: Author's calculation based on secondary data. SD, standard deviation, $\mathrm{n}=80$ countries. 


\subsection{STRUCTURAL EQUATION MODELING}

The structural equation modeling is based on theory, the features of which are shown in Figure 4. The circles represent constructs or latent variables, and their values reflect the variation explained by other latent variables using the SEM methodology (R2). The arrows connecting one construct to another represent the route coefficient (B), which estimates the constructs' direction, strength, and significance. The formative measurement is represented by arrows entering the corresponding construct. Finally, the rectangles represent formative indicators whose values contribute to understanding the construct, as they are not interchangeable.

Figure 4. PLS-Algorithm-Model estimation.

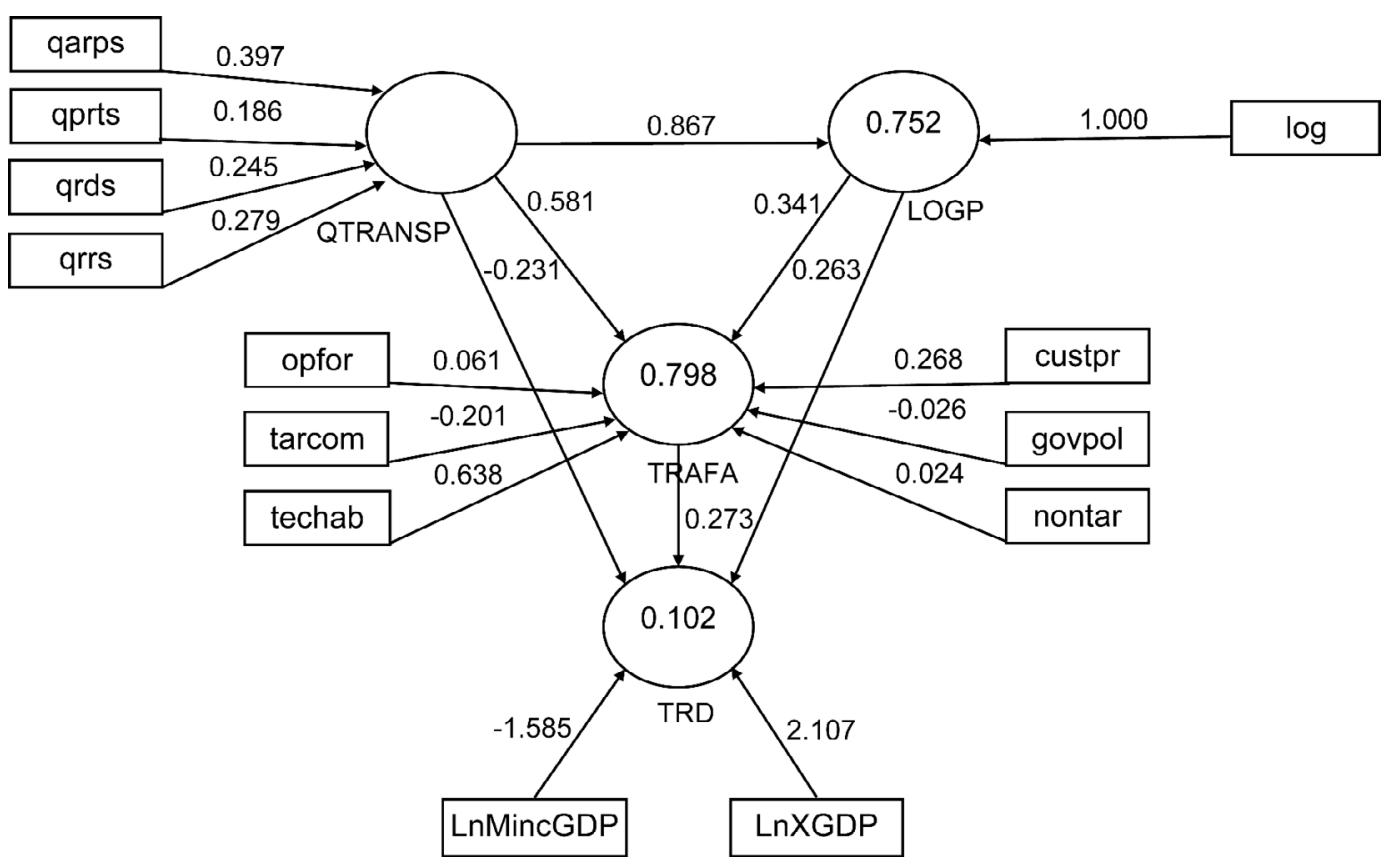

Figure 4. qtransp (quality of transportation infrastructure), qrds (quality of roads), qprts (quality of ports), qarps (quality of airports), qrrs (quality of railroads), logp (logistics performance), log (logistics), trafa (trade facilitation), tarcom (tariff complexity), govpol (government policymaking), opfor (openness to foreign markets), nontar (prevalence of trade barriers), custpr (customs procedures), techab (technology absorption), trd (trade), LnXGDP (exports of goods to GDP), LnMincGDP (imports of intermediate and capital goods to GDP)

Source: Author's calculation based on secondary data.

Notes: The model converged at 12 iterations (300 max) with a stop criterion $10^{-7}$ confirming the sample adequacy and enough variability of the data (Hair et al., 2017).

\subsection{STRUCTURAL MODEL-OUTER ASSESSMENT}

Confirmatory tetrad analysis (CTA-PLS) is used to empirically support the foundations of formative constructs with a minimum of four indicators (Hair, Risher, Sarstedt, \& Ringle, 2019). Furthermore, based on the idea of tetrad connections between pairs of covariances, the CTAPLS enables the evaluation of causal effects (Hair et al., 2017). Table 2 shows that the tetrads were significantly different from zero for Qtransp and Trafa, leading to a more accurate model setup (Hair et al., 2017, 2019). 
Table 2. CTA results.

\begin{tabular}{lllll}
\hline Construct & Tetrad & Sample & SD & T-statistic \\
\hline \multirow{2}{*}{ Qtransp } & 1.qarps, qprts, qrds, qrrs & 0.17 & 0.05 & $3.43^{* * *}$ \\
\cline { 2 - 5 } & 2.qarps, qprts, qrrs, qrds & 0.15 & 0.05 & $3.07 * * *$ \\
\hline \multirow{2}{*}{ Trafa } & 4.custpr, govpol, nontar, tarcom & -0.04 & 0.02 & $2.30^{* *}$ \\
\cline { 2 - 5 } & 6.custpr, nontar, tarcom, govpol & 0.04 & 0.01 & $2.93^{* * *}$ \\
\cline { 2 - 5 } & 7.custpr, govpol, nontar, techab & -0.02 & 0.01 & $3.06 * * *$ \\
\cline { 2 - 5 } & 10.custpr, govpol, opfor, tarcom & -0.09 & 0.02 & $4.06^{* * *}$ \\
\hline
\end{tabular}

Table 2. qtransp (quality of transportation infrastructure), qrds (quality of roads), qprts (quality of ports), qarps (quality of airports), qrrs (quality of railroads), trafa (trade facilitation), tarcom (tariff complexity), custpr (customs procedures), govpol (government policymaking), nontar (prevalence of trade barriers), opfor (openness to foreign markets), techab (technology absorption)

Source: Author's calculation based on secondary data. SD, standard deviation ${ }^{* *}$ and ${ }^{* *}$ represent significance at the $5 \%$ and $1 \%$ level, respectively.

Convergent validity of transportation infrastructure and trade facilitation was performed to verify their adequacy on the formative measurement model. The redundancy analysis was carried out; it requires a global indicator to convey the essence of the formative construct structure (Cheah, Sarstedt, Ringle, Ramayah, \& Ting, 2018; Sarstedt, Wilczynski, \& Melewar, 2013), which is confirmed when $B \geq 0.70$. As shown in Figures 5 and 6 , the convergent validity for Qtransp and Trafa is evident.

Figure 5. Convergent validity-Qtransp.

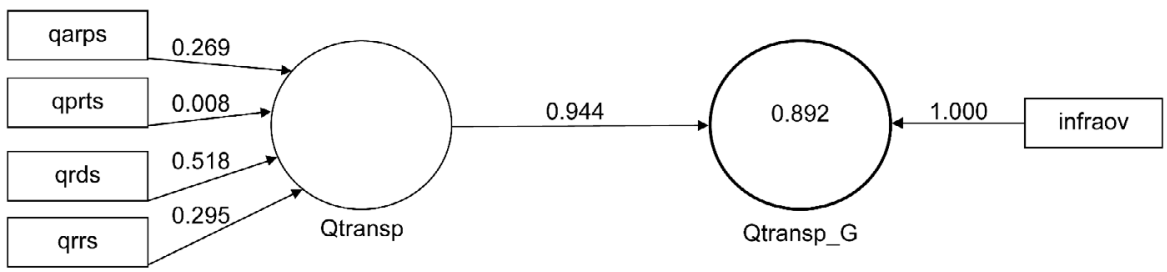

Figure 5. qtransp (quality of transportation infrastructure), qarps (quality of airports), qprts (quality of ports), qrds (quality of roads), qrrs (quality of railroads), qtransp_G (quality of transportation infrastructure global), infraov (infrastructure overall)

Source: Author's calculation based on secondary data.

Notes: The global item employed follows Sénquiz-Díaz (2021a) and is, "How do you assess your country's general state of infrastructure? [ $1=$ extremely underdeveloped, $7=$ extensive and efficient]" 
Figure 6. Convergent validity-Trafa.

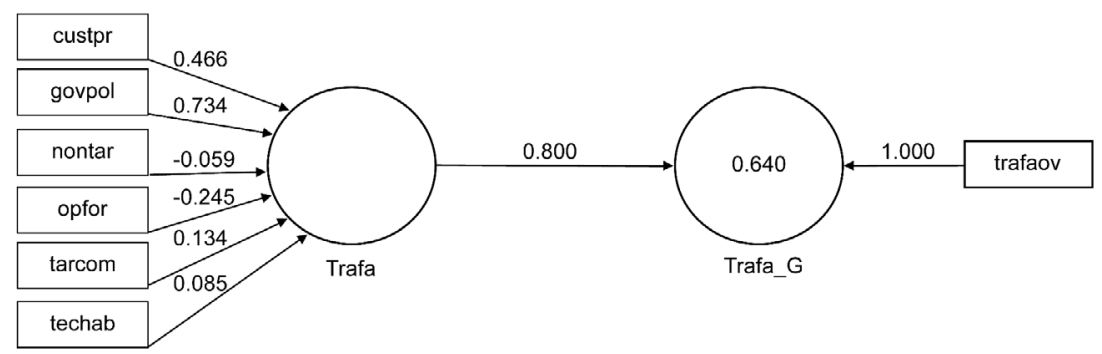

Figure 6. trafa (trade facilitation), custpr (customs procedures), govpol (government policymaking), nontar (prevalence of trade barriers), opfor (openness to foreign markets), tarcom (tariff complexity), techab (technology absorption)

Source: Author's calculation based on secondary data.

Notes: The global item used follows UNCTAD (2016) and is, "In your country, how efficiently does the government spend public revenue? [ $1=$ extremely inefficient, $7=$ extremely efficient in providing services and public goods]"

Cross-loadings were used to examine an item's correlation with the constructs (Lowry \& Gaskin, 2014). Table 3 shows the item's cross-loadings, showing the strongest relationship with constructs, and confirming the discriminant validity of the research variables.

Table 3. Cross-loadings-Discriminant validity.

\begin{tabular}{lllll}
\hline & Qtransp & Trafa & Logp & Trd \\
\hline Qarps & $\mathbf{0 . 9 4}$ & 0.82 & 0.81 & 0.22 \\
\hline Qprts & $\mathbf{0 . 8 9}$ & 0.79 & 0.75 & 0.20 \\
\hline Qrds & $\mathbf{0 . 9 2}$ & 0.81 & 0.80 & 0.19 \\
\hline Qrrs & $\mathbf{0 . 8 4}$ & 0.72 & 0.74 & 0.21 \\
\hline Custpr & 0.80 & $\mathbf{0 . 8 8}$ & 0.71 & 0.23 \\
\hline Govpol & 0.68 & $\mathbf{0 . 7 5}$ & 0.58 & 0.24 \\
\hline Nontar & 0.58 & $\mathbf{0 . 5 8}$ & 0.53 & 0.26 \\
\hline Opfor & 0.52 & $\mathbf{0 . 6 6}$ & 0.59 & 0.30 \\
\hline Tarcom & -0.49 & $\mathbf{0 . 6 0}$ & -0.53 & -0.22 \\
\hline Techab & 0.83 & $\mathbf{0 . 9 4}$ & 0.80 & 0.25 \\
\hline Log & 0.86 & 0.84 & $\mathbf{1 . 0 0}$ & 0.29 \\
\hline LnMincGDP & 0.10 & 0.12 & 0.07 & $\mathbf{0 . 2 9}$ \\
\hline LnXGDP & 0.19 & 0.23 & 0.19 & $\mathbf{0 . 6 9}$
\end{tabular}

Table 3. qtransp (quality of transportation infrastructure), qrds (quality of roads), qprts (quality of ports), qarps (quality of airports), qrrs (quality of railroads), logp (logistics performance), log (logistics), trafa (trade facilitation), tarcom (tariff complexity), govpol (government policymaking), opfor (openness to foreign markets), nontar (prevalence of trade barriers), custpr (customs procedures), techab (technology absorption), trd (trade), LnXGDP (exports of goods to GDP), LnMincGDP (imports of intermediate and capital goods to GDP)

Source: Author's calculations based on secondary data.

Multicollinearity checks were performed using variance inflation factors (VIF) to ensure that values do not exceed the recommended level of 10 (Lowry \& Gaskin, 2014; Menard, 2009). The results in 
Table 4 show that multicollinearity is not a problem $(<10)$.

Table 4. Indicator's variance inflation factor.

\begin{tabular}{ll}
\hline Indicator & VIF \\
\hline Qarps & 4.34 \\
\hline Qprts & 3.81 \\
\hline Qrds & 4.09 \\
\hline Qrrs & 2.26 \\
\hline Log & 1.00 \\
\hline Custpr & 4.80 \\
\hline Govpol & 3.17 \\
\hline Nontar & 2.27 \\
\hline Opfor & 1.89 \\
\hline Tarcom & 1.40 \\
\hline Techab & 2.79 \\
\hline LnMincGDP & 4.85 \\
\hline LnXGDP & 4.85
\end{tabular}

Table 4. qarps (quality of airports), qprts (quality of ports), qrds (quality of roads), qrrs (quality of railroads), log (logistics), custpr (customs procedure), govpol (government policymaking), nontar (prevalence of trade barriers), opfor (openness to foreign markets), tarcom (tariff complexity), techab (technology absorption), LnmincGDP (imports of intermediate and capital goods to GDP), LnXGDP (exports of goods to GDP)

Source: Author's calculation based on secondary data.

The indicator's outer weights $(\mathrm{w})$ determine the relative significance of the formative constructs based on the construct's multiple regressions on its set of indicators (Hair et al., 2017). Whether $\mathrm{w}$ is not substantial, the outer loadings (l) are considered when deciding whether to remove an indicator (Hair et al., 2017). Table 5 verifies the results, showing each indicator's importance on the corresponding construct definition. 
Table 5. Outer weights and loadings.

\begin{tabular}{|c|c|c|c|c|c|}
\hline & Indicator & Weight & T-statistic & Loading & T-statistic \\
\hline \multirow[t]{4}{*}{ Qtransp } & qarps & 0.39 & $4.82^{* * *}$ & -- & -- \\
\hline & qprts & 0.18 & $2.58^{\star * \star}$ & -- & -- \\
\hline & qrds & 0.24 & $3.66^{* * *}$ & -- & -- \\
\hline & qrrs & 0.27 & $5.51^{\star * *}$ & -- & -- \\
\hline \multirow[t]{6}{*}{ Trafa } & tarcom & -0.20 & $-3.75^{\star \star *}$ & -- & -- \\
\hline & govpol & -0.02 & -0.34 & 0.75 & $18.57^{\star * *}$ \\
\hline & opfor & 0.06 & 0.97 & 0.66 & $13.75^{\star \star *}$ \\
\hline & nontar & 0.02 & 0.39 & 0.68 & $14.19^{\star * *}$ \\
\hline & custpr & 0.26 & $2.36^{\star \star}$ & -- & -- \\
\hline & techab & 0.63 & $7.81^{\star \star *}$ & -- & -- \\
\hline \multirow[t]{2}{*}{ Trd } & LnMincGDP & -1.58 & $-2.33^{\star *}$ & -- & -- \\
\hline & LnXGDP & 2.10 & $3.35^{\star * *}$ & -- & -- \\
\hline
\end{tabular}

Table 5. qtransp (quality of transportation infrastructure), qrds (quality of roads), qprts (quality of ports), qarps (quality of airports), qrrs (quality of railroads), trafa (trade facilitation), tarcom (tariff complexity), govpol (government policymaking), opfor (openness to foreign markets), nontar (prevalence of trade barriers), custpr (customs procedures), techab (technology absorption), trd (trade), LnXGDP (exports of goods to GDP), LnMincGDP (imports of intermediate and capital goods to GDP)

Source: Author's calculation based on secondary data.

Notes: ${ }^{* \star}$ and ${ }^{\star *}$ represent significance at the $1 \%$ and $5 \%$ level, respectively.

\subsection{STRUCTURAL MODEL-INNER ASSESSMENT}

The inner evaluation of the structural model was performed before further analyses (Hair et al., 2017). Collinearity was considered, along with evaluation of the coefficient of determination (R2), hypothesis testing, and effect sizes (f2). The model assessment must consider VIF values between constructs to prevent overestimation of findings. Table 6 shows that multicollinearity is not a concern, as values are less than the highest suggested threshold $(<10)$. 
Table 6. Construct's relationship variance inflation factor.

\begin{tabular}{lc}
\hline Path relationship & VIF \\
\hline Trafa > Trd (H1) & 4.95 \\
\hline Qtransp > Logp (H2) & 1.00 \\
\hline Qtransp > Trafa (H3) & 4.03 \\
\hline Qtransp > Trd (H4) & 5.70 \\
\hline Logp > Trafa (H6) & 4.03 \\
\hline Logp > Trd (H7) & 4.61 \\
\hline
\end{tabular}

Table 6. trafa (trade facilitation), trd (trade), qtransp (quality of transportation infrastructure), logp (logistics performance)

Source: Author's calculation based on secondary data.

The R2 values explain a model's prediction by considering the sum of other constructions' impacts on an endogenous construct to establish its relationship (Hair et al., 2017). The results of the R2 and significant t-statistics are presented in Table 7.

Table 7. Structural model-R2 results.

\begin{tabular}{llc}
\hline Construct & R2 & T-statistic \\
\hline Logp & 0.75 & $31.60 * * *$ \\
\hline Trafa & 0.79 & $42.19 * * *$ \\
\hline Trd & 0.10 & $2.38 * *$ \\
\hline
\end{tabular}

Table 7. logp (logistics performance), trafa (trade facilitation) trd (trade)

Source: Author's calculation based on secondary data.

Notes: ${ }^{* \star}$ and ${ }^{\star \star}$ represent significance at the $1 \%$ and $5 \%$ level, respectively.

The bootstrapping procedure, a non-parametric method, was used to identify the structural relationships of the model (hypothesis testing) (Hair et al., 2017). As shown in Figure 7, estimations were based on 5,000 iterations (two-tailed at the 5\% significance level). The values embedded in the arrows represent the t-statistics; they were used to assess the significance of the hypotheses based on the following thresholds: $2.58(a=0.01), 1.96(a=0.05)$, and $1.65(a=0.10)$. 
Figure 7. Bootstrapping results.

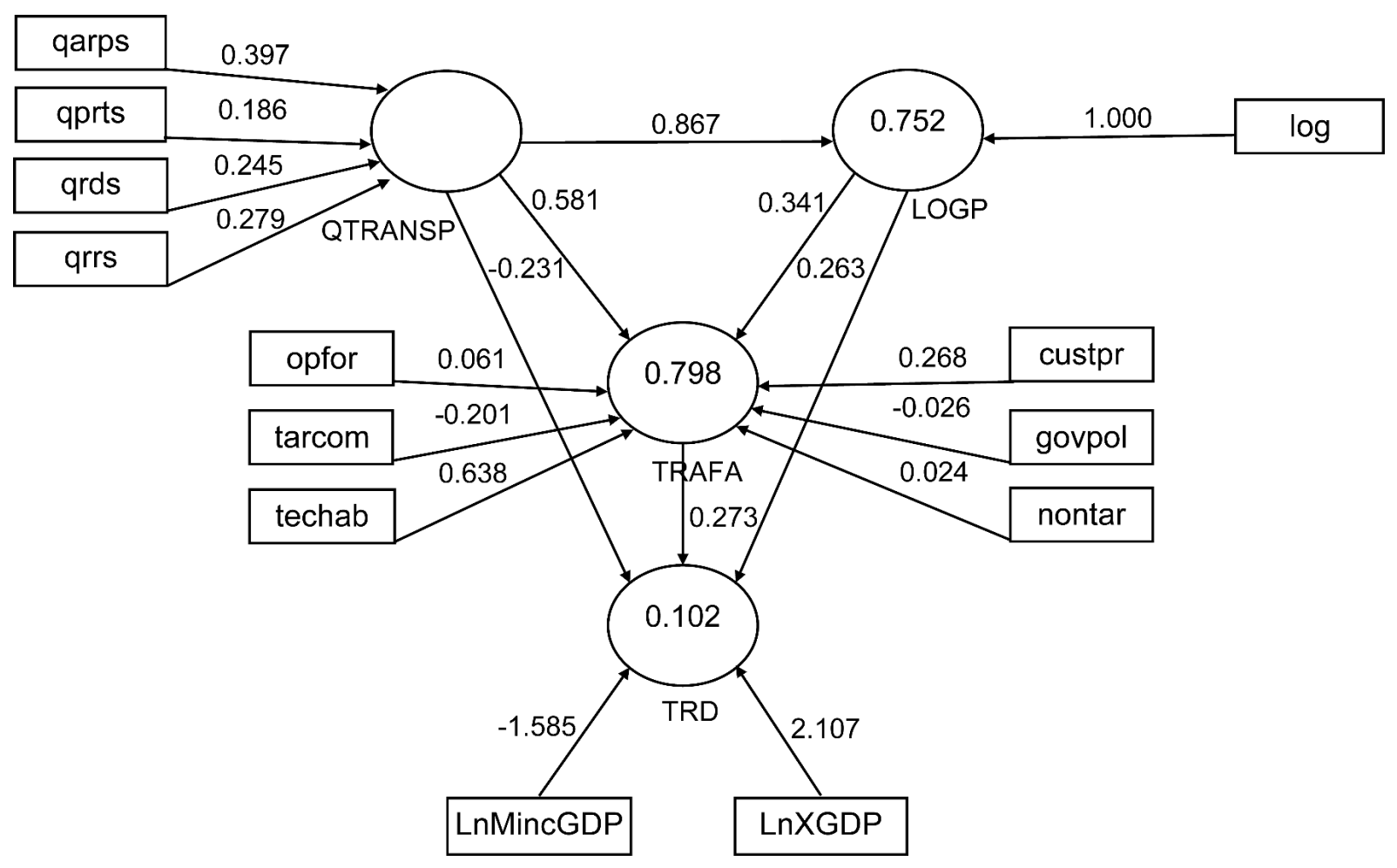

Figure 7. qtransp (quality of transportation infrastructure), qrds (quality of roads), qprts (quality of ports), qarps (quality of airports), qrrs (quality of railroads), logp (logistics performance), log (logistics), trafa (trade facilitation), tarcom (tariff complexity), govpol (government policymaking), opfor (openness to foreign markets), nontar (prevalence of trade barriers), custpr (customs procedures), techab (technology absorption), trd (trade), LnXGDP (exports of goods to GDP), LnMincGDP (imports of intermediate and capital goods to GDP)

Source: Author's calculation based on secondary data.

Notes: T-statistics denote a positive coefficient, since there is a no sign change default implemented in SmartPLS version 3.2.8 and later (https://www.smartpls.com/documentation/algorithms-andtechniques/bootstrapping).

The PLS algorithm analyzes the hypothesized relationships between the constructs through the path coefficients, where larger values indicate a stronger relationship (Hair et al., 2017). Previous bootstrapping results were used to examine t-statistics thresholds. $\mathrm{f} 2$ may be used to assess the relationships in the structural model, revealing (1) the practical and managerial relevance of the effects (Benitez, Henseler, Castillo, \& Schuberth, 2020) and (2) the relative impact of a predictor in an endogenous construct regardless of the sample size (Hair et al., 2017). This study employed Cohen's (1988) and Sawilowsky's (2009) effect size interpretation. Table 8 summarizes the results supporting the direct hypotheses, except for $\mathrm{H} 1, \mathrm{H} 4$, and $\mathrm{H} 7$. 
Table 8. Results for direct hypotheses and effect sizes.

\begin{tabular}{lccclll}
\hline Path Relationship & Sample & SD & T-statistic & F2 & Type & Decision \\
\hline Trafa > Trd (H1) & 0.27 & 0.18 & 1.48 & 0.01 & no effect & not supported \\
\hline Qtransp > Logp (H2) & 0.86 & 0.01 & $64.06^{* * *}$ & 3.03 & huge & supported \\
\hline Qtransp > Trafa (H3) & 0.58 & 0.07 & $7.44^{* * *}$ & 0.41 & large & supported \\
\hline Qtransp > Trd (H4) & -0.23 & 0.20 & -1.11 & 0.01 & no effect & not supported \\
\hline Logp > Trafa (H6) & 0.34 & 0.07 & $4.29 * * *$ & 0.14 & small & supported \\
\hline Logp > Trd (H7) & 0.26 & 0.17 & 1.44 & 0.01 & no effect & not supported \\
\hline
\end{tabular}

Table 8. trafa (trade facilitation), trd (trade), qtransp (quality of transportation infrastructure), logp (logistics performance)

Source: Author's calculation based on secondary data.

Notes: SD, standard deviation; ${ }^{* \star *}$ represents significance at the $1 \%$ level.

To examine the indirect effects of transport and logistics proposed by $\mathrm{H} 5$ and $\mathrm{H} 8$, this study followed the mediation analysis recommended by Zhao et al. (2010) and Hair et al. (2017), as shown in Figure 8. Path coefficients and P-values were used in the analysis, while the effect sizes were based on Cohen's (1988) and Sawilowsky's (2009) rules. Thus, P3 represents the direct effect; $\mathrm{P} 1{ }^{\star} \mathrm{P} 2$ is the indirect effect; and the total effect is the sum of both indirect and direct effects. This procedure identifies whether the direct effects of the independent variables in trade facilitation are strong enough to enhance trade. Tables 9 and 10 present the results.

Figure 8. Mediation model-Indirect hypotheses.

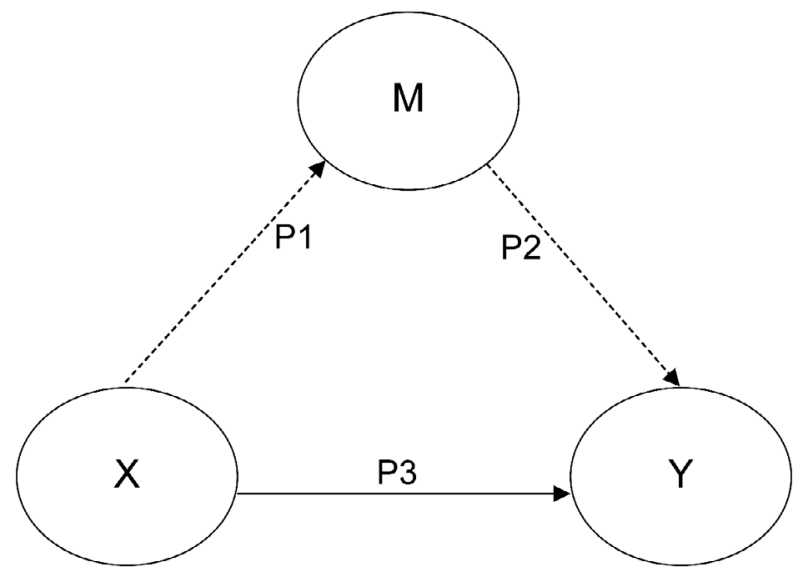

Figure 8. X (independent variable), Y (endogeneous variable), M (mediator variable) Source: Author's elaboration. 
Table 9. Analysis for H5.

\begin{tabular}{lcc}
\hline Path relationship & Path coefficient & P-value \\
\hline Qtransp > Trd (P3) & -0.23 & 0.23 \\
\hline Qtransp > Trafa (P1) & 0.58 & $<0.001$ \\
\hline Trafa > Trd (P2) & 0.27 & 0.13
\end{tabular}

Table 9. qtransp (quality of transportation infrastructure), trd (trade), trafa (trade facilitation)

Source: Author's calculation based on secondary data.

The analysis for $\mathrm{H} 5$ indicates that $\mathrm{P} 3=-0.23$ and $\mathrm{P} 1{ }^{\star} \mathrm{P} 2=0.15$. Therefore, the total effect size is -0.08 . The indirect path relationships are positive, and the P-value is statistically significant at the $1 \%$ level. While the quality of transportation infrastructure has an influencing effect on trade facilitation, the findings confirm that it is not enough to enhance trade. Therefore, H5 is not supported.

Table 10. Analysis for H8.

\begin{tabular}{lcc}
\hline Path relationship & Path coefficient & P-value \\
\hline Logp $>$ Trd (P3) & 0.26 & 0.13 \\
\hline Logp $>$ Trafa (P1) & 0.34 & $<0.001$ \\
\hline Trafa $>$ Trd (P2) & 0.27 & 0.13
\end{tabular}

Table 10. $\log$ (logistics performance), trd (trade), trafa (trade facilitation)

Source: Author's calculation based on secondary data.

The results for $\mathrm{H} 8$ show that $\mathrm{P} 3=0.26$ and $\mathrm{P} 1{ }^{\star} \mathrm{P} 2=0.09$, indicating a total effect size of 0.35 . In addition, the indirect path relationship has a positive direction and a statistical P-value at the $1 \%$ level, showing the indirect significance of logistics with a larger effect size for trade facilitation on trade, lending support to $\mathrm{H} 8$.

\section{DISCUSSION}

This research aimed to analyze the simultaneous direct and indirect effects among transportation infrastructure, logistics, trade facilitation, and trade. The PLS-SEM method was applied using a sample of 80 countries for 2012, 2014, and 2016. The study proposed that trade facilitation (H1), the quality of transportation infrastructure (H4), and logistics (H7) have positive effects on trade but found no significant direct effects. Nonetheless, the quality of transportation infrastructure proved to have a vast and significant positive effect size on logistics (H2) and a large effect size on trade facilitation (H3). Moreover, logistics has a positive effect on trade facilitation significant at the $1 \%$ level, albeit with a small effect size (H6). These results show that existing resources are not sufficient to enhance global trade among countries. The findings from the mediation analyses demonstrate the indirect effects of transportation infrastructure and logistics. Logistics has a stronger and larger effect size on trade via trade facilitation (H8) than transportation infrastructure does (H5). Thus, the significance of transportation infrastructure and logistics in trade should not be neglected, as the private sector (i.e., logistics providers) play a large and relevant role in practice. 


\section{CONCLUSION}

This investigation extends current research and theory, providing evidence of the simultaneous effects of different variables in diverse contexts in a theoretical model. Hence, it contributes to the international business field by increasing understanding of how stakeholders cope with global challenges (Buckley, Doh, \& Benischke, 2017). The research shows that incorporating the RBV, RD theory, and stakeholder theory in economic and social capital domains helps close the gaps between interdisciplinary and international business research. This study confirms the need for greater interaction among various stakeholders, both within and across borders. The positive effect of transportation infrastructure quality on logistics demonstrates the implications of RD of an economy. Governments and business leaders should collaborate to address common trade-related concerns so that businesses of all sizes can participate in global markets and geographic prospects, as suggested by stakeholder theory. Moreover, the increased engagement of the private sector (i.e., logistics providers) boosts government capital spending, leading to more industrial and firm-oriented policies in public management.The results show that trade facilitation implementation currently pursued by governments are insufficient to enhance trade. The findings indicate that business leaders value trade facilitation efforts from two points of view. The first perspective is ascribed to the relative importance of issues commonly addressed in trade agreements by governments and traderelated organizations, namely, tariff complexity, customs procedures, and technology absorption. The complexity of tariffs negatively affects trade facilitation. Therefore, tariff complexity may be a real burden affecting business opportunities for countries willing to increase their participation in global markets, as suggested by Hoekman and Nicita (2008) and the International Trade Forum (2013). As expected, improved customs procedures are a positive determinant of trade facilitation (Wilson et al., 2005) as its inefficiency jeopardizes international trade. Technology absorption also has a significant effect on trade facilitation. It provides better ways of working, including sharing information (UNCTAD, 2016) and facilitating trade increases (Freund \& Weinhold, 2004) while supporting better decision-making, particularly in foreign businesses. The second view of business leaders about of trade facilitation suggests there are exclusive and positive effects of government transparency in policymaking, opening to foreign markets, and non-tariff barriers. These findings suggest that government spending on these factors may favor the formulation of policies and regulations that increase trade facilitation. For instance, government policymaking transparency underlines the need to share information between stakeholders. Leaders may relate such importance to lowering transaction costs, reducing additional time for cross-border trade, and avoiding mistakes in shipping documentation, as suggested by UNCTAD (2016). Openness to foreign markets supports the interests of engaging in trade activities. In addition, the prevalence of non-tariff barriers is positive and significant for trade facilitation measurements. Since non-tariff barriers impact the competition of imported goods in the local country, this result could imply a protectionist measurement for foreign competition avoidance, which is highly present in regional trade. The study reveals far-reaching consequences for government officials and managers. First, possibilities in new global markets suggest that resources and networks are more important than ever, especially for countries willing to increase global exchanges. This requires a wider perspective than simply working on resources provided by the government. For example, a country's network development may enable a firm to minimize sourcing and inventory expenses while sustaining the efficiency of vertical global value chains. Similarly, companies may enhance short-term planning, providing the flexibility required for strategy formulation and last-minute implementation.

Logistics integration into the trade facilitation framework has the greatest impact on trade, deserving more government managerial attention. While transportation infrastructure has a significant and operational effect on logistics, governments should consider other factors before investing in new construction of these hard assets. In this way, governments should not exclusively depend on their transportation infrastructure quality while reducing their public capital investment competition with 
essential sectors, such as health. Such considerations and strategies could motivate, for example, non-exporting firms to adopt an export-led strategy regardless of their size and length of existence as well as open opportunities to augment imports to boost competitiveness. These remarks should not imply that the quality of transportation infrastructure is not relevant; instead, they highlight the significance of a country's network of services infrastructure. Inefficiency, lack of progress and collaboration, and non-tariff trade-related obstacles adversely put nations and businesses at risk. As a result, governments should consider logistics providers as crucial trade facilitation stakeholders to promote a more efficient corporate environment. Trade facilitation challenges remain, and further benefits may vary between countries by increasing logistics efficiency and resource use. Larger economies, for example, could develop service-oriented strategies, while smaller economies could develop opportunities to integrate tangible and non-tangible resources. In addition, countries transitioning from an agriculture-based economy to a more industrialized structure highly dependent on global value chains may increase their market benefits. This study concludes that additional elements must be considered when creating and executing tailored methods to boost a country's international trade, particularly to facilitate the import of goods. On the one hand, logistics stakeholders provide supplementary measures to optimize value chains without using additional economic and human resources from the government. On the other hand, the private sector must contribute to these issues with efficiency and a true desire to work alongside government officials. Overall, additional benefits can be achieved from actual implementation in which trade facilitation and logistics undoubtedly provide an interface and a stronger nexus for the government and business. This study has the following limitations. This study focused on fundamental trade components affecting a country's participation in foreign markets. However, other factors, such as the quality of education, should be considered. Another research opportunity is to analyze and make comparisons based on a country's development stage to identify demand. Regarding trade facilitation, for example, research employing cluster analyses is recommended to examine the advances in trade facilitation, particularly in least developed and developing countries. In addition, there are opportunities to perform longitudinal studies on the effects of logistics as more secondary data become available. Furthermore, studies analyzing institutional factors that promote a better logistics environment should be undertaken.

\section{ACKNOWLEDGMENTS}

The author declares that no research funding was received for this work. The current research is derived from Sénquiz-Díaz (2021c), to which some parts may converge. 


\section{REFERENCES}

Arvis, J., Ojala, L., Wiederer, C., Shepherd, B., Raj, A., \& Kiiski, T. (2018). Connecting to compete: Trade logistics in the global economy. World Bank. https://doi.org/10.1596/29971

Behar, A., Manners, P., \& Nelson, B. (2013). Exports and international logistics. Oxford Bulletin of Economics and Statistics, 75(6), 855-886. https://doi.org/10.1111/j.1468-0084.2012.00715.x

Benitez, J., Henseler, J., Castillo, A., \& Schuberth, F. (2020). How to perform and report an impactful analysis using partial least squares: Guidelines for confirmatory and explanatory IS research. Information \& Management, 57(2), 103168. https://doi.org/10.1016/j.im.2019.05.003

Buckley, P., Doh, J., \& Benischke, M. (2017). Towards a renaissance in international business research? Big questions, grand challenges, and the future of IB scholarship. Journal of International Business Studies, 48, 1045-1064. https://doi.org/10.1057/s41267-017-0102-z

Cheah, J.-H., Sarstedt, M., Ringle, C., Ramayah, T., \& Ting, H. (2018). Convergent validity assessment of formatively measured constructs in PLS-SEM: On using single-item versus multi-item measures in redundancy analyses. International Journal of Contemporary Hospitality Management, 30(11), 3192-3210. https://doi.org/10.1108/IJCHM-10-2017-0649

Cipollina, M., \& Demaria, F. (2020). The trade effect of the EU's preference margins and non-tariff barriers. Journal of Risk and Financial Management, 13(9), 203. http://dx.doi.org/10.3390/jrfm13090203

Cohen, J. (1988). Statistical power analysis for the behavioral sciences, 2nd ed. Hillsdale, NJ: Erlbaum.

Coltman, T., Devinney, T., Midgley, F., \& Venaik, S. (2008). Formative versus reflective measurement models: Two applications of formative measurement. Journal of Business Research, 61(12), 1250-1262. https://doi.org/10.1016/j.jbusres.2008.01.013

D’Aleo, V., \& Sergi, B. (2017). Does logistics influence economic growth? The European experience. Management Decision, 55(8), 1613-1628. https://doi.org/10.1108/MD-10-2016-0670

Fernández-Núñez, T., Maesso, M., \& Márquez, M. (2017). The role of imported inputs and FDI on economic growth: Evidence from emerging and advanced economies. Revista de Economía Mundial, 45, 65-86. Retrieved from http://www.redalyc.org/articulo.oa?id=86650984004

Freund, C., \& Weinhold, D. (2004). The effect of the internet on international trade. Journal of International Economics, 62(1), 171-189. https://doi.org/10.1016/S0022-1996(03)00059-X

Gani, A. (2017). The logistics performance effect in international trade. The Asian Journal of Shipping and Logistics, 33(4), 279-288. https://doi.org/10.1016/j.ajsl.2017.12.012

Grainger, A. (2011). Trade facilitation: A conceptual review. Journal of World Trade, 45(1), 39-62. Retrieved from http://eprints.nottingham.ac.uk/id/eprint/1769

Hair, J., Hult, G., Ringle, C., \& Sarstedt, M. (2017). A primer on partial least squares structural equation modeling (PLS-SEM), 2nd ed. Sage Publications.

Hair, J., Risher, J., Sarstedt, M., \& Ringle, C. (2019). When to use and how to report the results of PLS-SEM. European Business Review, 31(1), 2-24.

https://doi.org/10.1108/EBR-11-2018-0203

Hausman, W., Lee, H., \& Subramanian, U. (2013). The impact of logistics performance on trade. Production and Operations Management, 22(2), 236-252. https://doi.org/10.1111/j.1937-5956.2011.01312.x

Helpman, H., \& Krugman, P. (1989). Trade policy and market structure. Cambridge: The MIT Press. Herzer, D. (2007). How does trade composition affect productivity? Evidence for Chile. Applied Economic Letters, 14, 909-9212. https://doi.org/10.1080/13504850600690012 
Hill, C. (2011). International business: Competing in the global marketplace. New York: McGrawHill Irwin.

Hoekman, B. (2012). A 21st century trade agenda: Global supply chains and logistics services. World Bank. Retrieved from https://www.wto.org/english/forums_e/public_forum12_e/art_pf12_e/art5.htm

Hoekman, B., \& Nicita, A. (2008). Trade policy, trade costs and developing country trade. World Bank, Policy Research Working Paper 4797. https://doi.org/10.1596/1813-9450-4797

Hoekman, B., \& Nicita, A. (2010). Assessing the Doha Round: Market access, transactions costs and aid for trade facilitation. The Journal of International Trade \& Economic Development, 19(1), 65-79. https://doi.org/10.1080/09638190903327476

Hummels, D. (2007). Transportation costs and international trade in the second era of globalization. Journal of Economic Perspectives, 21(3), 131-154. Retrieved from https://pubs.aeaweb.org/doi/pdf/10.1257/jep.21.3.131

International Trade Forum. (2013). A trade facilitation agreement to increase LDC exports. http://www.tradeforum.org/article/A-trade-facilitation-agreement-to-increase-LDC-exports/

Kodongo, O., \& Ojah, K. (2016). Does infrastructure really explain economic growth in sub-Saharan Africa? Review of Development Finance, 6, 105-125. https://doi.org/10.1016/j.rdf.2016.12.001

Korinek, J., \& Sourdin, P. (2011). To what extent are high-quality logistics services trade facilitating? OECD Trade Policy Working Papers, No. 108, OECD Publishing. https://dx.doi.org/10.1787/5kggdthrj1zn-en

Kunaka, C., Mustra, M., \& Saez, S. (2013). Trade dimensions of logistics services: A proposal for trade agreements. World Bank, Policy Research Working Paper. https://doi.org/10.1596/1813-9450-6332

Kuznets, S. (1959). Six lectures on economic growth. New York: The Free Press of Glencoe.

Lakshmanan, T. (2008), "The wider economic benefits of transportation," The wider economic benefits of transport: Macro-, meso- and microeconomic transport planning and investment tools. Paris: OECD Publishing. https://doi.org/10.1787/9789282101834-4-en.

Lean, H., Huang, W., \& Hong, J. (2014). Logistics and economic development: Experience from China. Transport Policy, 32, 96-104.https://doi.org/10.1016/j.tranpol.2014.01.003

Lee, J.-W. (1995). Capital goods imports and long-run growth. Journal of Development Economics, 48(1), 91-110. https://doi.org/10.1016/0304-3878(95)00015-1

Lian, W., Novta, N., Pugacheva, E., Timmer, Y., \& Topalova, P. (2019). The price of capital goods: A driver of investment under threat. IMF Working Paper WP/19/134.

Limão, N., \& Venables, A. (2001). Infrastructure, geographical disadvantage, transport costs, and trade. The World Bank Economic Review, 15(3), 451-479. https://doi.org/10.1596/1813-9450-2257

Lowry, P., \& Gaskin, J. (2014). Partial least squares (PLS) structural equation modeling (SEM) for building and testing behavioral causal theory: When to choose it and how to use it. IEEE Transactions on Professional Communication, 57(2), 123-146. https://doi.org/10.1109/TPC.2014.2312452

Mann, C. (2012). Supply chain logistics, trade facilitation and international trade: A macroeconomic policy view. Journal of Supply Chain Management, 48(3), 7-14. https://doi.org/10.1111/j.1745-493X.2012.03270.x

Márquez-Ramos, L., Martínez-Zarzoso, I., \& Suárez-Burget, C. (2012). Trade policy versus trade facilitation: An application using 'good old' OLS. Economics, 6, April 5. http://dx.doi.org/10.5018/economics-ejournal.ja.2012-11 
Martí, L., Puertas, R., \& García, L. (2014). Relevance of trade facilitation in emerging countries' exports. The Journal of International Trade \& Economic Development, 23(2), 202-222. https://doi.org/10.1080/09638199.2012.698639

Menard, S. (2009). Logistic regression: From introductory to advanced concepts and applications. Thousand Oaks, CA: Sage Publications.

Munemo, J., Bandyopadhyay, S., \& Basistha, A. (2006), "Chapter 21 foreign aid and export performance: A panel data analysis of developing countries," Lahiri, S. (Ed.), Theory and practice of foreign aid (frontiers of economics and globalization, Vol. 1). Bingley: Emerald Group Publishing Limited, 421-433. https://doi.org/10.1016/S1574-8715(06)01021-9

Munim, Z. H., \& Schramm, H.-J. (2018). The impacts of port infrastructure and logistic performance on economic growth: The mediating role of seaborne trade. Journal of Shipping Trade, 3, 1. https://doi.org/10.1186/s41072-018-0027-0

Organisation for Economic Co-operation and Development, OECD. (2013). Understanding the value of transport infrastructure. International Transport Forum. Retrieved from https://www.itf-oecd.org/sites/default/files/docs/13value.pdf

Organisation for Economic Co-operation and Development, OECD. (2020). Tackling coronavirus (COVID-19) contributing to a global effort-Trade facilitation ad COVID-19 pandemic. Retrieved from https://read.oecd-ilibrary.org/view/?ref=130_130609v8jn83j1j3\&title=Trade-facilitation-and-the-covid-19-pandemic

Portugal-Pérez, A., \& Wilson, J. (2010). Export performance and trade facilitation reform: Hard and soft infrastructure. World Bank, Policy Research Working Paper 5261. https://doi.org/10.1596/1813-9450-5261

Ringle, C. M., Wende, S., \& Becker, J.M. (2015). SmartPLS 3. Bönningstedt: SmartPLS. Retrieved from https://www.smartpls.com

Rodrigue, J.-P., \& Comtois, C. (2017). "Transportation and commercial geography, Rodrigue, J.-P., Comtois, C., \& Slack, B. (Eds.), The geography of transport systems. New York: Routledge, 20-28.

Sarstedt, M., Wilczynski, P., \& Melewar, T. (2013). Measuring reputation in global markets-A comparison of reputation measures' convergent and criterion validities. Journal of World Business, 48(3), 329-339. https://doi.org/10.1016/j.jwb.2012.07.017

Saslavsky, D., \& Shepherd, B. (2014). Facilitating international production networks: The role of trade logistics. The Journal of International Trade \& Economic Development, 23(7), 979-999. https://doi.org/10.1080/09638199.2013.811534

Sawilowsky, S. (2009). New effect size rules of thumb. Journal of Modern Applied Statistical Methods, 8(2), 597-599. https://doi.org/10.22237/jmasm/1257035100

Sénquiz-Díaz, C. (2021a). Effect size of logistics: Evidence from selected countries. LOGIScientific Journal on Transport and Logistics, 12(1), 123-134.

https://doi.org/10.2478/logi-2021-0012

Sénquiz-Díaz, C. (2021b). Transport infrastructure quality and logistics performance in exports. Economics, 9(1), 107-124. https://doi.org/10.2478/eoik-2021-0008

Sénquiz-Díaz, C. (2021c). Trade facilitation and logistics: A management interface for government and business. Unpublished doctoral dissertation. Universidad Ana G. Méndez.

Skorobogatova, O., \& Kuzmina-Merlino, I. (2017). Transport infrastructure development performance. Procedia Engineering, 178, 319-329.

https://doi.org/10.1016/j.proeng.2017.01.056

United Nations. (2013). International merchandise trade statistics: Compilers manual, Revision 1-Department of Economics and Social Affairs, Statistics Division. Retrieved from https://unstats.un.org/unsd/trade/publications/seriesf_87Rev1_e_cover.pdf 
United Nations Conference on Trade and Development, UNCTAD. (2016). Trade facilitation and development-Driving trade competitiveness, border agency effectiveness and strengthened governance. Retrieved from https://unctad.org/system/files/official-document/dtltlb2016d1_en.pdf

Veeramani, C. (2008). Impact of imported intermediate and capital goods on economic growth: A cross country analysis. Indira Gandhi Institute of Development Research, Mumbai. https://dx.doi.org/10.2139/ssrn.1325181

Wilson, J., Mann, C., \& Otsuki, T. (2003). Trade facilitation and economic development: A new approach to quantifying impact. The World Bank Economic Review, 17(3), 367-389. https://doi.org/10.1093/wber/lhg027

Wilson, J., Mann, C., \& Otsuki, T. (2005). Assessing the potential benefit of trade facilitation: A global perspective. The World Economy, 28(6), 841-871. https://doi.org/10.1111/j.1467-9701.2005.00709.x

World Trade Organization. (n.d.). Regional trade agreements. Retrieved from https://www.wto.org/english/tratop_e/region_e/region_e.htm

Yadav, N. (2014). Impact of trade facilitation on parts and components trade. The International Trade Journal, 28, 287-310. https://doi.org/10.1080/08853908.2014.922040

Yang, C., \& Lirn, T. (2017). Revisiting the resource-based view on logistics performance in the shipping industry. Industrial Journal of Physical Distribution \& Logistics Management, 47(9), 884-905. https://doi.org/10.1108/IJPDLM-05-2017-0184

Zhang, J., Li, F., Yu, L., \& Cheng, B. (2019). An assessment of trade facilitation's impacts on China's forest product exports to countries along the "Belt and Road" based on the perspective of ternary margins. Sustainability, 11(5), 1298. https://doi.org/10.3390/su11051298

Zhao, X., Lynch, J., \& Chen, Q. (2010). Reconsidering Baron and Kenny: Myths and truths about mediation analysis. Journal of Consumer Research, 37, 197-206. Retrieved from https://psycnet.apa.org/doi/10.1086/651257 
Algeria, Argentina, Armenia, Australia, Austria, Belgium, Bolivia, Botswana, Brazil, Bulgaria, Cambodia, Cameroon, Canada, Chile, China, Colombia, Costa Rica, Croatia, Czech Republic, Denmark, Egypt, Estonia, Ethiopia, Finland, France, Georgia, Germany, Greece, Hong Kong, Hungary, India, Indonesia, Ireland, Italy, Japan, Jordan, Kazakhstan, Korea Republic, Kyrgyz Republic, Latvia, Lithuania, Luxembourg, Macedonia, Madagascar, Malaysia, Mauritania, Mexico, Moldova, Montenegro, Namibia, Netherlands, New Zealand, Nigeria, Norway, Pakistan, Panama, Perú, Philippines, Poland, Portugal, Romania, Russian Federation, Saudi Arabia, Senegal, Serbia, Slovak Republic, Slovenia, South Africa, Spain, Sweden, Switzerland, Tanzania, Thailand, Turkey, Ukraine, United Kingdom, United States, Uruguay, Vietnam, Zimbabwe

Corresponding regions: Europe and Central Asia (39 countries), Sub-Saharan Africa (11 countries), East Asia and Pacific (12 countries), Latin America (10 countries), Middle East and North Africa (4 countries), South Asia ( 2 countries), and North America (2 countries). 


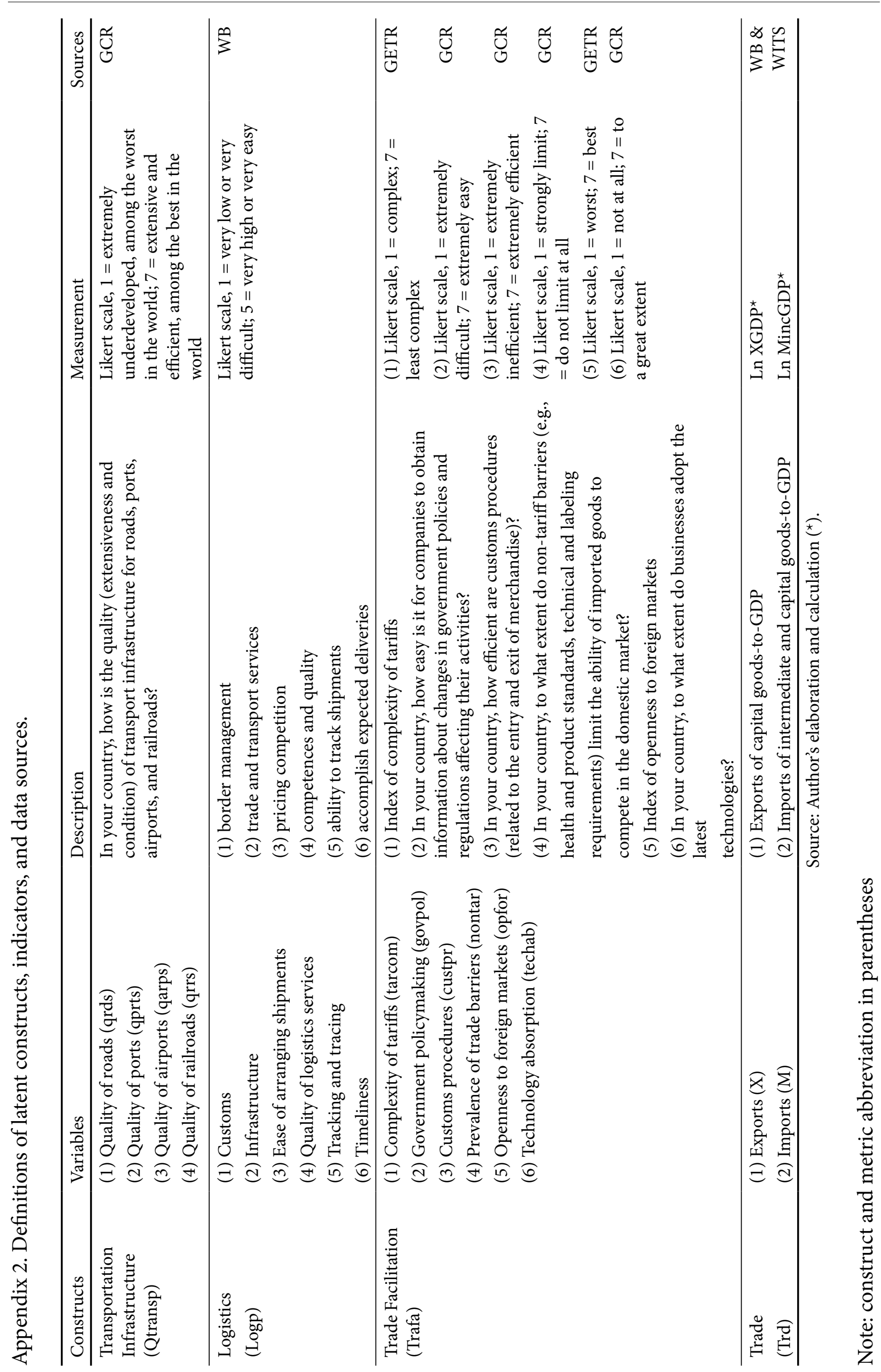

